\title{
MENGUJI ASAS DROIT DE SUITE \\ DALAM JAMINAN FIDUSIA ${ }^{1}$
}

\author{
Oleh : \\ I Made Sarjana \\ Desak Putu Dewi Kasih \\ I Gusti Ayu Kartika
}

\begin{abstract}
The principle of droit de suite is one of the most important principles in the law of guarantee, especially in fiduciary security. The principle implies that the rights of the creditor as the recipient of the fiduciary objects continue to follow the object of guarantee, wherever the object is, to guarantee the repayment of the debts of the debitor. The rights which are owned by the creditor as the recipient of fiduciary security in the principle seem to be absolute, but in fact if it is related to de practice, the principle of droit de suite has certain limitations.

The limitations of this principle is whon it is faced with higher interest, the individual rights owned by the recipient of fiduciary must succumb, as in the case of illegal logging, which once was decided to test the Forestry Law by the Constitutional Court (Case Decision Number 012/PUU-III/2005). Although the State can perform fiduciary deprivation of the object which is used for committing illegal logging, but from the aspect of material criminal law, it cannot be done immediately to destroy the object of guarantee, since object of the fiduciary collateral, is not considered a dangerous thing. Whereas, from the legal aspects of criminal procedure, if the case has been decided, then there is a duty of the State to return the object of fiduciary to those who own it.

From the aspect of civil law, the creditor as recipient of fiduciary who feel harmed as a result of illegal logging practices may have standing to sue for damages under Article 1365 of Burgerljik Wetboek. The provision is used, because the act of illegal logging is an act against the law and there are losses caused to the recipient of fiduciary.
\end{abstract}

Keywords: principle of droit de suite, fiduciary, limitations.

\section{PENDAHULUAN}

\subsection{Latar Belakang Masalah}

Paling tidak terdapat dua prinsip yang dikenal dalam hukum perbankan yakni prinsip kepercayaan dan prinsip

Karya ilmiah ini merupakan hasil penelitian yang dibiayai dari dana Dipa BLU Program Studi Magister (S2) Ilmu Hukum PPS UNUD dengan SK Rektor nomor: 2120/UN.14.4/HK/2014, telah di presentasikan dalam seminar/FGD di Program Magister (S2) Ilmu Hukum pada tanggal 30 Oktober 2014.

2 Penulis adalah Dosen pada Program Magister (S2) Ilmu Hukum Program Pascasarjana UNUD. kehati-hatian ${ }^{3}$. Antara kedua prinsip tersebut adalah saling berkaitan dan saling membutuhkan, nyaris tidak dapat dipisahkan untuk mengembangkan industri perbankan. Prinsip kepercayaan tersebut timbul karena adanya kehati-hatian dan kehati-hatian tersebut harus tetap dilakukan untuk tetap tumbuhnya rasa kepercayaan. Kepercayaan dapat dilihat dari dua sisi, yakni dari sisi

Djoni S Gazali dan Rachmadi Usman, Hukum Perbankan, Sinar Grafika, Jakarta 2010, hlm. 18. 
industri perbankan dan dari sisi masyarakat sebagai nasabah. Industri Perbankan tidak akan ada tanpa didukung oleh nasabah untuk menggunakan jasa-jasa yang ditawarkan oleh perbankan. Dalam perkembangan ekonomi sekarang masyarakat tidak akan dapat berbuat banyak tanpa ada dunia perbankan untuk mengelola keuangan yang dihimpun dari masyarakat. Kepercayaan adalah salah satu prinsip yang mutlak harus dimiliki oleh industri perbankan. Perbankan harus mampu memperlihatkan jati dirinya kepada masyarakat sebagai lembaga keuangan yang layak dipercaya khususnya terhadap nasabah penyimpan dana. Sebaliknya nasabah peminjam dana juga harus dapat dipercaya oleh pihak perbankan sebagai penyalur dana yang dibutuhkan oleh masyarakat. Nasabah peminjam dana yang sering disebut sebagai debitur diwajibkan melakukan prestasi sesuai dengan isi perjanjian kredit yang telah disepakati.

Prinsip kehati-hatian mutlak dipelihara dalam dunia perbankan. Pihak bank untuk menjaga reputasinya untuk mengelola dana diwajibkan untuk selalu bersikap hati-hati. Prinsip kehati-hatian tersebut diwujudkan sebelum menyalurkan kredit kepada calon penerimanya dengan jalan melakukan analisis terhadap beberapa hal yang disebut dengan 5 C yaitu: character (watak), capacity (kemampuan), capital (modal), collateral (agunan), condition of economy (prospek usaha dari nasabah debitur). ${ }^{4}$ Dari kelima hal tersebut, yang paling berkaitan dengan lembaga jaminan adalah tentang collateral (agunan). Secara yuridis keberadaan agunan

Ibid. hlm.272. tidak harus ada dalam setiap penyaluran kredit. Hal tersebut merupakan persyaratan teknis administrasi dan bersifat preventif dalam rangka menjaga kredit yang akan disalurkan. Agunan sebagai jaminan yang diberikan oleh nasabah debitur yang diterima oleh pihak bank selaku kreditur, untuk dapat dimanfaatkan oleh pihak kreditur manakala pihak debitur tidak mampu melunasi kredit yang telah dipinjamnya. Salah satu lembaga jaminan di Indonesia untuk mengamankan kredit adalah jaminan fidusia. Sebagaimana diketahui bahwa benda yang dijadikan obyek jaminan didalam lembaga jaminan fidusia masih tetap berada di tangan pihak debitur selaku penerima kredit. Berbeda halnya dengan lembaga jaminan gadai yang obyek jaminannya tidak dipegang oleh nasabah debitur selaku penerima kredit. Hakikatnya keberadaan lembaga jaminan fidusia adalah untuk membantu nasabah debitur bahwa obyek jaminan yang tidak diserahkan kepada kreditur adalah agar dapat digunakan untuk melakukan usaha, sehingga hasil usaha tersebut digunakan untuk melunasi utangnya kepada pihak kreditur. Tujuan mulia tersebut tidak selalu dimanfaatkan sebagaimana mestinya. Salah satu praktik yang pernah terjadi adalah obyek jaminan fidusia digunakan untuk melakukan kejahatan seperti melakukan tindakan illegal logging. ${ }^{5}$

Sementara disisi lain terdapat beberapa asas yang ada dalam hukum jaminan sebagai bagian dari hukum benda. Asas yang paling berkaitan dengan hal tersebut adalah asas preference dan asas droit de suite. Asas

Kasus tersebut pernah diajukan ke Mahkamah Konstitusi: Jurnal Konstitusi, Vol.3. No. 2 Mei 2006 
preference adalah asas yang dimiliki oleh pihak kreditur pemegang jaminan yang disebut sebagai kreditur preference. Kreditur preference adalah kreditur diutamakan penyelesaian kreditnya dari hasil penjualan obyek jaminan tersebut, sedangkan asas droit de suite merupakan asas yang menyatakan bahwa dimanapun obyek jaminan berada selalu diikuti oleh hak-hak dari pihak kreditur sebagai penerima jaminan. Dari peristiwa tersebut terjadi kontradiktif antara asas preference dan asas droit de suite dengan perampasan obyek jaminan fidusia yang dilakukan oleh negara untuk kepentingan penyidikan. Kontradiktif tersebut dapat terjadi apabila obyek jaminan tersebut tidak dikembalikan kepada pihak kreditur penerima jaminan atau kredit yang diterima oleh pihak debitur sudah jatuh tempo dan tidak terbayarkan sementara obyek jaminan belum dikembalikan atau dalam keadaan rusak. Dengan demikian keberadaan pihak kreditur berada dalam posisi yang lemah, tidak mendapatlan perlindungan hukum sebagaimana mestinya. Apabila demikian maka asas-asas tersebut belum memberikan perlindungan yang maksimal terhadap pihak kreditur pemegang jaminan fidusia. Kelemahan tersebut seharusnya dapat ditutupi dengan ketentuan yang lain untuk dapat memperkuat posisi pihak kreditur bilamana obyek jaminan fidusia dipakai untuk melakukan kejahatan.

\subsection{Rumusan Masalah}

Berdasarkan pada latar belakang sebagaimana telah diuraikan diatas, maka permasalahan yang diungkap adalah: Apakah pihak kreditur pemegang jaminan fidusia sudah mendapatkan pelindungan hukum sesuai dengan prinsip-prinsip hukum jaminan?

\section{METODE PENELITIAN}

\subsection{Tipe Penelitian}

Penelitian yang dilakukan adalah penelitian hukum, hal ini beranjak dari bahwa Ilmu Hukum merupakan disiplin yang bersifat Sui Generis, ${ }^{6}$ ilmu hukum memiliki karakter yang khas yaitu bersifat normatif. Berdasarkan sifat normatifnya itu ilmu hukum merupakan ilmu yang mempelajari tentang eksistensi, sifat, substansi, prosedur dan tujuan norma atau kaedah hukum. Aspek yang paling esensial dari norma hukum adalah sebagai kaedah untuk mengatur perilaku subyek hukum. Ilmu hukum bukan sematamata meneliti kaedah, melainkan meneliti tetang berlaku tidaknya kaedah hukum, tentang apa yang seyogyanya dilakukan (preskriptif). ${ }^{7}$ Menurut Peter M Marzuki, penelitian hukum adalah sasarannya untuk menjawab isu hukum. Setidaknya ada tiga hal harus ditemukan dalam proses penelitian yaitu: aturan hukum, prinsip-prinsip hukum, ataupun doktrin-doktrin atau pendapat sarjana yang berwibawa guna menjawab isu hukum yang dihadapi ${ }^{8}$. Penelitian hukum ini dilakukan untuk menghasilkan argumentasi

\footnotetext{
Sui Generis artinya dari kodratnya (Ranuhandoko, Terminologi Hukum, Sinar Grafika, Jakarta 2006, hlm. 508). Menurut jenis atau golongannya sendiri (Martin Basiang, The Contemporary Law Dictionary, Red \& White Publishing, Indonesia, 2009,h. 415), Of its own kind, Unique, of its own particular type; in a class of its own (Webster's New World Law Dictionary, Wiley Publishing, Inc. 2006, hlm.247).

Sudikno Mertokusumo, Penemuan Hukum Sebuah Pengantar. Cet. Kelima Liberty Yogyakarta.2007 hlm. 29 (selanjutnya disebut Sudikno Mertokusumo (I).

8 Peter Mahmud Marzuki, Penelitian Hukum, Kencana Prenada Media Group, Jakarta, 2006, hlm. 35 (selanjutnya disebut Peter M Marzuki I).
} 
terhadap perlindungan hukum kreditur pemegang jaminan fidusia.

\subsection{Jenis Pendekatan Penelitian}

Kegiatan penelitian ini dilakukan denganbeberapapendekatanyaitupendekatan undang-undang (statute approach), dan pendekatan konsep (conceptual approach). Pendekatanundang-undang merupakan suatu pengkajian terutama peraturan perundangundangan serta regulasi yang bersangkut paut dengan isu hukum guna melindungi kepentingan kreditur pemegang jaminan fidusia, khususnya UU No. 49 Tahun 1999 Tentang Fidusia, Burgerlijk Wetboek (BW) Indonesia, serta Kitab Undang-Undang Hukum Pidana (KUHP) dan Kitab UndangUndang Hukum Acara Pidana (KUHAP).

Analisis terhadap perundang-undangan tersebut dilakukan dengan cara sebagai berikut:

Pada tataran dogmatika hukum, akan dilakukan diskripsi, sistimatisasi, dan evaluasi tentang perundang-undangan yang berkaitan dengan hukum jaminan dan secara khusus akan dianalisis UU No. 49 Tahun 1999 Tentang Fidusia, BW Indonesia, KUHP dan KUHAP. Pada tataran teori hukum akan dianalisis tentang pengaturan prinsip-prinsip atau asas-asas yang melandasi hukum jaminan khususnya jaminan fidusia.

Pendekatan konseptual beranjak dari pendapat-pendapat dan doktrin-doktrin dari para sarjana yang terkemuka dalam bidangnya serta berkembang di dalam ilmu hukum. Pendekatan ini diharapkan akan menemukan ide-ide yang melahirkan pengkajian terhadap persoalan hukum, yang relevan untuk menjawab isu hukum yang dihadapi.

\subsection{Bahan Hukum}

Kegiatan penelitian ini menggunakan baik bahan hukum primer maupun bahan hukum sekunder. Menurut Black's Law Dictionary pengertian bahan hukum (source of law) adalah: "Something (such as constitution, treaty, statute, or custom) that provides authorities for legislation and for yudicial decision; a point of origin for law or legal analysis".

Dijelaskan lebih lanjut perihal bahan hukum meliputi:

Dalam konteks penelitian hukum, kata sumber hukum merujuk pada tiga konsep yang berbeda. Pertama, sumber hukum yang merujuk pada keaslian konsep danidehukum; kedua, sumber hukum yang dapat merujuk pada lembaga pemerintah yang membuat peraturan-peraturan hukum; ketiga, sumber hukum yang merujuk pada publikasi yang berwujud hukum. Buku-buku, data base computer, microforms, serta media lain yang berisi informasi tentang hukum atau semua sumber hukum?.

Bertolak dari uraian definisi tersebut, maka dalam penelitian ini bahan hukum primer adalah segala bentuk peraturan perundang-undangan seperti UU No. 42 Tahun 1999 Tentang Fidusia, BW Indonesia, KUHP dan KUHAP. Sedangkan bahan hukum sekunder adalah buku-buku teks yang berkaian dengan isu hukum yang sedang di tulis, artikel-artikel yang ditulis dalam jurnal-jurnal hukum.

Bryan A Garner, Black's Law Dictionary, Eighth Edition, West, a Thomson Business St. Paul, MN, 2004, hlm.1429. 


\subsection{Prosedur Pengumpulan dan Analisis Bahan Hukum}

Penelitian dilakukan dalam 2 (dua) tahap yaitu kegiatan pengumpulan bahanbahan hukum. Pengumpulan yang dimaksud tiada lain merupakan suatu inventarisasi terhadap bahan-bahan hukum primer ataupun sekender ${ }^{10}$. Pengumpulan bahan hukum tersebut dilakukan lewat inventarisasi hukum positip dan penelusuran kepustakaan terkait dengan isu hukum yang akan diteliti. Terhadap semua bahan-bahan yang telah diinventarisir, kemudian dilakukan pengkajian, dipaparkan, sistematisasi, dianalisis dan diinterpretasi, sehingga diharapkan dalam penelitian ini dapat mengkajidanmemecahkanpermasalahannya. Pemaparan material penelitian merupakan langkah pertama setiap penelitian ilmiah ${ }^{11}$ Pemaparan tersebut bukan saja menyangkut isi, tetapi juga struktur hukum positip, artinya untuk melakukan kegiatan untuk menentukan segala yang berada di dalamnya atau fungsi, manfaat aturan hukum.

Interpretasi terhadap bahan hukum primer dilakukan dalam hal terjadi kekaburan terhadap aturan hukum tersebut. Bruggink mengelompokkan interpretasi kedalam 4 model yaitu: interpretasi bahasa, historis undang-undang, sistematis dan kemayarakatan. Interpretasi dalam penelitian ini yang dilakukan adalah penafsiran bahasa, oleh karena bahasa memegang peranan yang penting dan mendasar untuk mengetahui makna yang terkandung dalam setiap bunyi

10 Sunaryati Hartono C.F.G, Penelitian Hukum Di Indonesia Pada Akhir Abad ke 20, Alumni Bandung.1994, hlm.134 (selanjutnya disebut Sunaryati Hartono I).

11 Bernard Arief Sidharta, Refleksi Tentang Struktur Ilmu Hukum. Mandar Maju.Bandung,.2000,hlm.43. aturan perundang-undangan. Penafsiran sistematis juga digunakan dalam hal ini oleh karena perlu untuk mengetahui keterkaitan peraturan perundang-undangan baik secara vertikal maupun secara horizontal, sehingga dapatdiketahuikeharmonisanataukesesuaian dan keterkaitan antara satu peraturan dengan peraturan lainnya. Pada kesempatan ini bukan hanya diketahui formalitasnya akan tetapi yang paling penting adalah kesesuaian prinsip-prinsip hukum jaminan.

\section{HASIL DAN PEMBAHASAN}

\subsection{Pengaturan Perlindungan Penerima} Jaminan Fidusia.

Ketentuan Pasal 24 UUJF memuat tentang tanggung jawab pihak pemberi jaminan fidusia akibat perbuatannya. ${ }^{12}$ Ketentuan Pasal 24 UUJF tersebut dapat dipahami secara rasional karena sangat memungkinkan obyek jaminan fidusia akan disalahgunakan sehubungan obyek jaminan tersebut tidak berada pada tangan kreditur sebagai penerima fidusia. Dalam praktiknya susah untuk mengawasinya karena pihak debitur dapat berbuat apa saja lebih-lebih sudah mengetahui dirinya tidak akan mampu untuk melakukan kewajiban untuk melaksanakan prestasinya sesuai dengan perjanjian yang dilakukan. Seketika juga timbul niat yang tidak baik untuk berbuat sesuai dan mengingkari kepercayaan yang telah diberikan berdasarkan prinsip-prinsip dalam jaminan fidusia.

Pasal 24 UUJF menentukan penerima fidusia tidak menanggung kewajiban atas akibat tindakan atau kelalaian pemberi fidusia baik yang timbul dari hubungan kontraktual atau yang timbul dari perbuatan melanggar hukum sehubungan dengan penggunaan dan pengalihan benda yang menjadi obyek jaminan. 
Tidak ada ketentuan lain yang memberikan perlindungan kepada kreditur penerima fidusia apabila pihak debitur pemberi fidusia melakukan perbuatan melanggar hukum berkaitan dengan penggunaan obyek jaminan fidusia. Perlindungan tersebut hanyalah sebatas sebagaimana ditentukan oleh Pasal 20 UUJF yang menyebutkan bahwa jaminan fidusia tetap mengikuti benda yang menjadi obyek jaminan fidusia dalam tangan siapapun benda tersebut berada,.......dst. Ketentuan tersebut memuat asas droit de suite, namun dalam pelaksanaannya tidak semudah yang diucapkan. Tidak ada juga ketentuan yang menyebutkan apabila obyek jaminan fidusia digunakan untuk kejahatan dan dirampas untuk negara. Bagaimana kedudukan dari obyek jaminan tersebut, bagaimana kewajiban pemberi fidusia selanjutnya serta bagaimana hak dari penerima obyek jaminan selanjutnya. Tidak ada ketentuan yang menyatakan pemberian ganti rugi seketika kepada penerima fidusia dan lain sebagainya sebagai akibat dari perbuatan melanggar hukum pihak debitur pemberi fidusia.

\subsection{Asas Droit De Suite}

Pasal 20 UUJF memberikan angin segar kepada penerima jaminan fidusia karena kepentingannya terlindungi yang mengesankan bahwa ketika obyek jaminan berada pada tangan orang lain, maka ia memiliki kewenangan untuk mengambilnya. Dengan demikian pasal tersebut memuat asas droit de suite untuk memberikan kepastian hukum terhadap penerima jaminan fidusia. ${ }^{13}$
Pengakuan asas tersebut menunjukkan bahwa jaminan fidusia merupakan hak kebendaan (zakelijkrecht), sebaliknya bukan merupakan hak perorangan (persoonlijkrecht). Oleh karena merupakan hak kebendaan maka hak jaminan fidusia dapat dipertahankan terhadap siapapun dan berhak menuntut siapa saja yang menggangu hak tersebut. Pengakuan asas droit de suite merupakan hak jaminan yang mengikuti bendanya dalam tangan siapapun benda tersebut berada guna memberikan kepastian hukum bagi kreditur pemegang jaminan fidusia untuk memperoleh pelunasan hutang dari hasil penjualan obyek jaminan fidusia apabila debitur pemberi jaminan fidusia tidak memenuhi kewajibannya atau wanprestasi. Kepastian hukum atas hak tersebut bukan saja pada saat benda jaminan fidusia berada pada debitur pemberi jaminan fidusia, tetapi juga ketika benda jaminan fidusia telah berada pada pihak ketiga.

Asas droit de suite tidak berlaku terhadap semua benda bergerak sebagai obyek jaminan fidusia. Terhadap bendabenda yang dikecualikan adalah terhadap benda persediaan. Namun sangat disayangkan bahwa UUJF tidak menjelaskan apa saja yang termasuk sebagai benda persediaan. Hanya berdasarkan penjelasan Pasal 23 ayat (2) UUJF yang diberikan penjelasan secara negatif yaitu bahwa yang tidak merupakan benda persediaan antara lain mesin produksi, mobil pribadi atau rumah pribadi. Disisi lain dalam penjelasan umum angka 3 UUJF menyebutkan bahwa

\footnotetext{
Pasal 20 UUJF menentukan jaminan fidusia tetap mengikuti benda yang menjadi obyek jaminan fidusia dalam tangan siapapun benda tersebut berada, kecuali pengalihan atas benda persediaan yang menjadi obyek jaminan fidusia". Dalam penjelasannya menyebutkan bahwa ketentuan ini mengakui prinsip "droit de suite" yang telah merupakan bagian dari peraturan perundang-undangan yang berlaku dalam kaitannya dengan hak mutlak atas kebendaan (in rem).
} 
sebelum UUJF dibentuk pada umumnya benda yang menjadi obyek jaminan fidusia adalah benda bergerak yang terdiri dari benda dalam persediaan (inventory), benda dagangan, piutang, peralatan mesin dan kedaraan bermotor. Karena penjelasannya sangat sumir yang menjadikan semakin tidak jelas, maka memunculkan kekaburan atau ketidak pastian terhadap benda apa saja yang termasuk sebagai benda persediaan yang dikecualikan oleh UUJF. Walaupun terhadap benda persediaan secara akademis dapat dilakukan penafsiran secara a contrario terhadap penjelasan yang disebutkan oleh penjelasan Pasal 23 UUJF, tetapi tetap juga masih menyisakan masalah. Contoh yang dapat disampaikan disini adalah beberapa kendaraan atau mobil dagangan yang terdapat di show room yang belum merupakan mobil pribadi, maka seharusnya termasuk sebagai benda persediaan. Apabila mobil tersebut yang belum merupakan mobil pribadi ikut dikecualikan oleh UUJF maka akan mendapatkan kesulitan selanjutnya karena masing-masing mobil memiliki nomor kerangka dan nomor mesinnya masingmasing berbeda satu dengan lainnya.

Diantara asas lain yang berkaitan dengan asas droit de suite tersebut adalah asas etikad baik (good faith) karena berperan kepada pemberi fidusia sebagai pihak debitur. Memang batasan dengan etikad baik sulit ditentukan, namun demikian pada umumnya dapat dipahami bahwa itikad baik merupakan kewajiban moral. Perjanjian tidak dapat menampung segala hal yang memiliki peran yang sangat penting dalam pembuatan ataupun pelaksanaanya. Jadi apa yang mengikat bukan hanya apa saja yang secara eksplisit tertuang dalam perjanjian, melainkan juga apa yang menurut etikad baik juga diharuskan. Dalam sistem hukum perjanjian kita prinsip etikad baik diatur dalam Pasal 1338 (3) BW Indonesia yang menekankan adanya keharusan bagi para pihak untuk melaksanakan perjanjian dengan etikad baik. Sejalan dengan pemikiran teoritis serta praktik bisnis yang berkaitan dengan perjanjian, maka ketentuan tersebut ditafsirkan secara luas (extensive interpretation) yang kemudian menghasilkan ketentuan bahwa etikad baik tidak saja berlaku pada tahap pelaksanaan, tetapi juga pada tahap sebelum penutupan perjanjian (pre-contractual fase) ${ }^{14}$.

Terdapat dua makna etikad baik. Pertama dalamkaitannya dengan pelaksanaan kontrak sebagaimana ditentukan dalam Pasal 1338 (3) BW Indonesia. Dalam kaitannya dengan pelaksanaannya etikad baik (bona fides) diartikan perilaku yang patut dan layak antar kedua belah pihak. Pengujian apakah suatu perilaku itu patut dan adil didasarkan pada norma-norma yang tidak tertulis. Kedua, etikad baik juga diartikan sebagai keadaan tidak mengetahui adanya cacat, seperti misalnya pembayaran dengan etikad baik sebagaimana diatur dalam Pasal 1386 BW Indonesia.

Pelaksanaan kontrak merupakan pelaksanaan hak dan kewajiban para pihak sesuai dengan klausula yang telah disepakati dalam kontrak. Fungsi etikad baik dalam tahap ini terutama menyangkut fungsi membatasi dan meniadakan kewajiban kontraktual. Fungsi ini tidak boleh dijalankan

Lihat Yohanes Sogar Simamora, 2009, Hukum Perjanjian Prinsip Hukum Kontrak Pengadaan Barang dan Jasa oleh Pemerintah, LaksBang PRESSindo, hlm.43. 
begitu saja, melainkan hanya apabila terdapat alasan yang sangat penting dan mendesak. Pembatasan tersebut hanya dapat dilakukan apabila suatu klausula tidak dapat diterima karena tidak adil. Etikad baik bahkan juga mempunyai fungsi menambah kewajiban kontraktual ${ }^{15}$.

\subsection{Hak Dalam Hukum Jaminan.}

Beberapa pengertian dari hak menurut pandangan dari para sarjana adalah sebagai berikut: menurut Sudikno Mertokusumo, hak adalah kepentingan yang dilindungi oleh hukum, sedangkan kepentingan adalah tuntutan perseorangan atau kelompok yang diharapkan untuk dipenuhi. ${ }^{16}$ Dalam kamus umum bahasa Indonesia menyebutkan, hak adalah kekuasaan, wewenang, benar, sungguh-sungguh, nyata, milik, kepunyaan martabat, kekuasaan untuk menuntut sesuatu, kekuasaan yang benar atas sesuatu. ${ }^{17}$ Menurut pakar lain hak adalah kekuasaan, sehingga kekuasaan tersebut dapat dipertahankan kepada setiap orang. Hal tersebut mengandung arti bahwa setiap orang harus mengakui, menghormati, dan mengindahkan kekuasaan itu. Bahwa yang memberikan hak tersebut adalah hukum. Hak merupakan sesuatu yang harus dihormati, dihargai dan diberikan kepada yang berhak sesuai dengan porsinya. ${ }^{18}$

Lihat Ibid. hlm. 44-45.

16 Sudikno Mertokusumo,2005, Mengenal Hukum Suatu Pengantar, Liberty Yogyakarta, hlm. 43(selanjutnya disebut Sudikno,M II).

17 Sultan Muhamad Zein, Kamus Umum Bahasa Indonesia, Sinar Harapan, Jakarta 1996 : 140

18 M. Yatimin Abdullah,2006,Pengantar Studi Etika, Raja Grafindo, Jakarta, hlm.93.
Lawan dari hak adalah kewajiban. Kewajiban merupakan keharusan untuk melakukan atau tidak melakukan sesuatu perbuatan tertentu atas tuntutan satu orang atau lebih yang berhak. Secara umum ada tiga macam kewajiban yaitu: kewajiban hukum, kewajiban alamiah dan kewajiban moral. Kewajiban yang perlu diperhatikan dalam hal ini adalah kewajiban hukum. Kewajiban hukum adalah kewajiban yang harus dipenuhi, sebab apabila kewajiban hukum tersebut tidak dipenuhi akan menimbulkan akibat hukum, yaitu adanya tuntutan dari mereka yang merasa berhak agar kewajiban dari pihak lain dipenuhinya. Jadi kewajiban tersebut timbul dari perikatan, baik perikatan yang lahir dari perjanjian ataupun yang lahir dari undang-undang .

Hak dalam hubungannya dengan asas droit de suite yang terdapat dalam hukum jaminan dan dikaitkan dengan perampasan obyek jaminan fidusia oleh negara, didasarkan pada teori hak. Pengertian hak dapat dijumpai dalam teori mengenai hakekat hak. Menurut Lord Lloyd of Hamstead dan M.D.A. Freeman terdapat dua teori mengenai hakekat hak yaitu teori kehendak yaitu menitik beratkan kepada kehendak atau pilihan dan yang lainnya adalah teori kepentingan atau teori kemanfaatan. Kedua teori tersebut berkaitan dengan tujuan hukum. ${ }^{19}$

Antara kedua teori mengenai hakekat hak tersebut saling berseberangan satu dengan yang lainnya. Menurut teorikehendak sebagaimana dianut oleh H.L.A. Hart, untuk

Peter Mahmud Marzuki, 2008,Pengantar Ilmu Hukum, Prenada Media Group,hlm.172 (selanjutnya disebut Peter M Marzuki II). 
mencapai tujuan hukum, maka individu diberikan kebebasan tentang apa yang dikehendakinya. Teori tersebut memandang bahwa pemegang hak dapat berbuat apa saja atas haknya. Pemegang hak dapat berbuat apa saja atas hak itu, dapat melaksanakan, melepaskan serta dapat tidak menggunakan haknya itu. Apa yang dilakukan tersebut merupakan pilihannya, sehingga ciri khas yang paling menonjol adalah bahwa individu dapat melakukan diskresi sebagai pemegang hak. ${ }^{20}$

Teori kepentingan atau kemanfaatan dianut anatara lain oleh J. Bentham, Raz, Cempbell, yang menyebutkan bahwa tujuan hukum bukanlah untuk melindungi kehendak individu, melainkan untuk melindungi kepentingan-kepentingan tertentu, sehingga hak itu adalah sebagai kepentingankepentingan yang dilindungi oleh hukum. Karena kepentingan-kepentingan itu bukan ciptaan oleh negara melainkan sudah ada dalam kehidupan bermasyarakat, maka negara memilih mana yang harus dilindungi. ${ }^{21}$

Dari kedua teori yang disebutkan diatas, apabila dikaitkan dengan keberadaan asas droit de suite dalam jaminan fidusia dan adanya kewenangan negara merampas obyek jaminan fidusia yang digunakan untuk melakukan kejahatan, maka dapat digunakan untuk melakukan analisis terhadap perampasan obyek jaminan fidusia tersebut.

Ibid. hlm.175.

Ibid.

\subsection{Perampasan Obyek Jaminan Fidusia.}

Arti perampasan adalah pengambilan dengan paksaan. $^{22}$ Perampasan yang dilakukan oleh yang berwenang merupakan tindakan yang dilakukan dengan paksaan berdasarkan peraturan perundangundangan terhadap mereka yang melakukan pelanggaran hukum.

Berikut ini disajikan kasus yang pernah terjadi berkaitan dengan penebangan hutan secara illegal (illegal logging). ${ }^{23}$ Kasus tersebut diketahui dari permohonan judicial review terhadap Undang-Undang No. 41 Tahun 1999 Tentang Kehutanan sebagaimana telah diubah berdasarkan Undang-Undang No. 19 Tahun 2004 yang menetapkan Perpu No. 1 Tahun 2004 menjadi undang-undang (selanjutnya disebut UU Kehutanan). Permohonan uji meteriil tersebut dilakukan oleh PT. Astra Sedaya Finance. Adapun ketentuan yang dimohonkan untuk diuji adalah Pasal 78 Ayat (15) UU Kehutanan. ${ }^{24}$

PT. Astra Sedaya Finance sebagai penerima fidusia menganggap hak dan/ atau kewenangan konstitusionalnya dirugikan oleh berlakunya UU Kehutanan tersebut. Pemohon menyatakan bahwa hak konstitusionalnya yang dirugikan adalah hak akan kepastian hukum yang adil sebagaimana

http://artikata.com/arti-3468-rampas.html.25/07/2014 diolah dari Henry Subagyo, Jaminan Fidusia Dalam Upaya Pemberantasan "Illegal Logging", Jurnal Konstitusi Vol. 3 No. 2 Mei 2006.

24 Pasal 78 Ayat (15) UU Kehutanan yang menentukan bahwa: "semua hasil hutan dari hasil kejahatan dan pelanggaran dan atau alat-alat termasuk alat angkutnya yang dipergunakan untuk melakukan kejahatan dan atau pelanggaran sebagaimana dimaksud dalam pasal ini dirampas untuk negara". Dan penjelasannya menentukan bahwa: "yang termasuk alat angkut antara lain kapal, tongkang, truk, trailer, ponton tugboat, perahu layar, heli kopter dan lain-lain”. 
diatur dalam Pasal 28 D ayat (1) UUD 1945, hak atas perlindungan harta benda yang berada dibawah kekuasaannya sebagaimana diatur dalam Pasal 28G ayat (1) UUD 1945] dan hak untuk mempunyai hak milik yang tidak boleh diambil secara sewenangwenang oleh siapapun sebagaimana diatur dalam Pasal 28H ayat (4) UUD 1945. Selain itu perampasan terhadap benda obyek jaminan fidusia yang dilakukan oleh pihak kejaksaan telah melanggar hak kepemilikan yang telah beralih pada pemohon (PT. Astra Sedaya Finance) berdasarkan perjanjian jaminan fidusia. Dilain sisi berkaitan dengan permohonan tersebut pemerintah memberi keteranganantaralain,telahmenjadikebijakan pemerintah untuk melakukan pemberantasan illegal logging yang telah merugikan negara dalam jumlah yang cukup besar. Dari jumlah kerugiannya, illegal logging merupakan kejahatan yang memiliki dampak yang luar biasa (extra ordinary crime) dan dari modus operandinya illegal logging merupakan kejahatan terorganisir (organized crime) dengan indikasi keterlibatan masyarakat, aparat pemerintah dan penegak hukum serta para pengusaha sebagai cukong dan bersifat lintas negara pula. Dengan meningkatnya kasus illegal logging, kerugian negara tidak hanya bersifat ekonomis, melainkan juga berdampak secara sosial dan menimbulkan kerusakan lingkungan serta meningkatkan potensi bencana.

Berdasarkan atas permohonan tersebut, pertimbangan Majelis Hakim Konstitusi menyatakan antara lain:

- Hak milik yang telah dilindungi oleh ketentuan UUD NRI 1945 tidak saja bersifat absolut melainkan pelaksanaannya wajib tunduk kepada pembatasan yang ditentukan oleh undang-undang dengan maksud sematamata untuk kepentingan keamanan dan ketertiban umum sebagaimana tercantum dalam Pasal 28J ayat (2) UUD 1945.

- Ketentuan Pasal 78 ayat (15) UU Kehutananadalahuntukmenjagakepentingan yang lebih tinggi yaitu kepentingan nasional dari tindakan illegal logging yang telah dan semakin merajalela, sehingga secara tidak langsung mengganggu dan membahayakan hak asasi orang lain, merugikan negara, membahayakan ekosistem dan kelangsungan kehidupan.

- Hak milik yang didalilkan pemohon tidak sama dengan hak milik yang didasarkan pada hubungan sebagaimana halnya antara pemegang hak milik dengan obyek hak milik (inheren), sehingga perlindungan hukumnya tidak dapat diperlakukan sama terlebih lagi untuk kepentingan yang lebih besar.

- Tidak setiap perampasan hak milik sebagaimana yang dilakukan dalam kasus itu serta merta bertentangan dengan UUD NRI 1945. Sepanjang perampasan tersebut telah dilakukan sesuai dengan kaedahkaedah hukum acara, maka tindakan dari aparat hukum tidak menyalahi prinsip due process of law. Meskipun demikian hak milik dari pihak ketiga dengan etikad baik harus dilindungi.

Kajian yuridis tentang jaminan fidusia:

Bahwa fidusia merupakan bagian dari hak jaminan yang diatur dalam UUJF. Dari ketentuan Pasal 1 ayat $1 \mathrm{UUJF}^{25}$ dapat

25 Pasal 1 ayat 1 UUJF menentukan bahwa: Fidusia adalah pengalihan hak kepemilikan suatu benda atas dasar kepercayaan dengan ketentuan bahwa benda yang hak kepemilikannya dialihkan tersebut tetap dalam penguasaan pemilik benda. 
dilakukan klarifikasi adalah sebagai berikut: terhadap unsur (1) tentang pengalihan hak kepemilikan suatu benda atas dasar kepercayaan, dapatmemunculkan pertanyaan apakah memang benar telah terjadi peralihan hak milik pada saat dilakukan perjanjian jaminan fidusia? Menurut pandangan doktriner bahwa pengalihan hak milik atas dasar kepercayaan sebagaimana ditentukan dalamPasal 1 ayat 1 UUJF tersebuttidakbenar menjadikan kreditur secara langsung sebagai pemilik atas benda yang telah dijaminkan seperti halnya kepemilikan benda secara umum. Hal itu hanyalah untuk memberikan hak jaminan saja pada kreditur sebagaimana tujuan dari kata "pengalihan" tersebut tidak lain hanyalah untuk memberikan jaminan atas suatu pemenuhan hak tagihan atas eksekusi terhadap jaminan ${ }^{26}$. Demikian juga halnya apabila memperhatikan makna kata "atas dasar kepercayaan" dapat ditafsirkan bahwa dengan pengalihan terhadap benda tersebut tidak menyebabkan pihak kreditur benar-benar sebagai pemilik atas benda jaminan. Bahwa obyek jaminan tersebut hanya berfungsi sebagai benda untuk dilakukan eksekusi manakala pelunasan utangnya tidak diselesaikan sebagaimana mestinya. Apabila utangnya dilunasi oleh phak debitur maka obyek jaminan fidusia akan kembali kepada pemberi fidusia. Jadi jaminan fidusia hanya berfungsi sebagai agunan, untuk kepentingan pelunasan utang tertentu, memberikan kedudukan yang diutamakan kepada penerima fidusia terhadap kreditur lainnya dari kewajiban debitur sebagai pemberi fidusia ${ }^{27}$.

H. Tan Kamelo,2004,Hukum Jaminan Fidusia, Alumni Bandung,hlm.190-191.

$27 \quad$ Ibid, hlm.160-162.
Memperhatikan kasus perampasan alat-alat yang digunakan dalam rangka illegal logging maka hal tersebut dapat dikaji berdasarkan pada teori tentang hakekat hak, sehingga dapat diterima secara rasional. Sebagaimana telah disebutkan diatas ada dua teori yang mendasar mengenai hakekat hak, yang pertama teori dari Hart yang mengagung-agungkan hak yang dimiliki oleh setiap individu yang sifatnya bebas. Dalam arti pemilik suatu hak dapat saja menggunakan haknya tanpa batasan dari siapapun, ia dapat berbuat apa saja terhadap hak yang dimilikinya tersebut. Sedangkan teori hakekat hak lainnya sebagaimana dianut oleh J. Bentham serta pakar lainnya menyatakan bahwa hak itu bukan untuk melindungi kepentingan individu, akan tetapi untuk melindungi kepentingan-kepentingan tertentu, sehingga hak itu dilindungi oleh hukum.

Berkaitan dengan perampasan alatalat atau benda yang digunakan untuk illegal loging dan disesuaikan dengan pertimbangan dari majelis hakim Mahkamah Konstitusi, tentunya didasarkan pada perlindungan terhadap kepentingan-kepentingan tertentu, bukan mempersoalkan adanya kepentingan yang individualistik. Dengan demikian pertimbangan majelis hakim dapat kiranya diterima karena illegal logging termasuk sebagai kejahatan yang luar biasa (extra ordinary crime), yang dapat merugikan banyak orang dan merusak lingkungan. Dalam hal ini putusan majelis hakim lebih mengedepankan kepentingan orang banyak daripada kepentingan individu semata-mata. Kepentingan individu di Indonesia tidaklah bersifat absolut, mereka secara invidual tidak dapat menggunakan haknya secara bebas 
tanpa menghiraukan kepentingan yang lebih besar.

Sebagaimana diuraikan diatas mengenai perbedaan kepentingan antara kepentingan individu dan kepentingan masyarakat lebih luas, ternyata konstitusi kita juga telah mengaturnya berdasarkan Pasal 28J UUD 1945. ${ }^{28}$ Memperhatikan kaedah yang diatur dalam ketentuan tersebut, maka hak seseorang memiliki batasan-batasan sehingga setiap orang tidak dapat menjalankan hak dan kebebasannya tersebut secara absolut. Dengan demikian agar tidak terjadi pelanggaran terhadap hak orang lain, maka dilakukanlah pembatasan yang ditetapkan dengan undang-undang. Namun demikian pembatasan tersebut haruslah nyata-nyata hanya dengan tujuan hukum untuk menjamin pengakuan serta penghormatan terhadap hak dan kebebasan orang lain, dan untuk memenuhi tuntutan rasa keadilan yang didasarkan pada pertimbangan moral, nilai agama, keamanan dan ketertiban umum dalam suatu masyarakat ${ }^{29}$.

Berdasarkan ketentuan konstitusi tersebut, maka perampasan yang dilakukan oleh negara dalam tindakan illegal logging merupakan perampasan yang didasarkan pada peraturan perundang-undangan dan tidak bertentangan dengan konstitusi,

28 1)Setiap orang wajib menghormati hak asasi manusia orang lain dalam tertib kehidupan kemasyarakatan, berbangsa dan bernegara.

2).Dalam menjalankan hak dan kebebasannya, setiap orang wajib tunduk kepada pembatasan yang ditetapkan dengan undang-undang dengan maksud semata-mata untuk menjamin pengakuan serta penghormatan atas hak dan kebebasan orang lain dan untuk menjamin tuntutan yang adil sesuai dengan pertimbangan moral, nilai-nilai agama, keamanan, dan ketertiban umum dalam suatu masyarakat demokratis.

29 Henry Subgyo, Op.Cit, hlm.98. karena perbuatan illegal logging tersebut dari perspektif sosial, ekonomi, hak, ketertiban umum, serta moralitas sangat merugikan bahkan juga perbuatan tersebut dapat merusak lingkungan yang bersifat kemerosotan terhadap nilai lingkungan khususnya tanah.

\subsection{Kajian Berdasarkan KUHP dan KUHAP}

Masing-masing terdapat satu pasal dalam KUHP dan KUHAP yang berkaitan dengan persoalan perampasan terhadap barang-barang dari pelaku tindakan kejahatan yaitu Pasal 39 ayat (1) KUHP dan Pasal 42 KUHP. ${ }^{30}$ Kedua ketentuan tersebut adalah untuk menjernihkan hubungannya dengan kejahatan illegal logging dengan aspek hukum pidana yang diatur dalam hukum acara pidana dan hukum pidana materiil.

Memperhatikan kedua ketentuan tersebut, nampaknya perampasan yang dilakukan tersebut adalah perampasan terhadap barang-barang milik terpidana yang diperoleh dari hasil kejahatan. Jadi dalam ketentuan tersebut seseorang yang barangnya dirampas adalah ketika ia sudah menjadi terpidana, dengan kata lain apabila ia belum menjadi terpidana maka barangnya tidak dapat dirampas, barang tersebut hanyalah sebagai alat bukti saja. Sementara pada perbuatan illegal loging, perampasan terhadap barang-barang sudah dilakukan

Pasal 39 Ayat (1) KUHP menentukan: barang-barang kepunyaan terpidana yang diperoleh dari kejahatan atau yang disengaja dipergunakan untuk melakukan kejahatan dapat dirampas. Pasal 42 KUHP menentukan bahwa: segala biaya untuk pidana penjara dan pidana kurungan dipikul oleh negara, dan segala pendapatan dari pidana denda dan perampasan menjadi milik negara. 
sebelum seseorang yang melakukan tindakan illegal logging menjadi terpidana. Ketentuan dalam Pasal 39 KUHP tersebut tidak dapat atau tidak tepat digunakan sebagai dasar hukum untuk perampasan terhadap perbuatan illegal logging, karena seseorang yang barang-barangnya dirampas ketika melakukan perbuatan illegal logging bukan seorang terpidana. Sedangkan ketentuan Pasal 42 KUHP tersebut dalam kaitannya dengan perampasan untuk barang-barang perbuatan illegal logging adalah juga tidak tepat, karena perampasan menjadi milik negara sebagaimana ditentukan dalam Pasal 42 KUHP tersebut adalah barang-barang yang benar-benar sifatnya membahayakan oranglain maupun lingkungannya, disamping memang barangnya dilarang untuk dimiliki, juga terdapat barang yang disalahgunakan. Yang perlu diperhatikan bahwa Pasal 42 KUHP merupakan suatu rangkaian yang tidak dapat dipisahkan dengan Pasal 39 KUHP, sehingga sasarannya adalah terhadap barang-barang milik seseorang yang telah menjadi terpidana.

Terdapat perbedaan karakter dalam perampasan barang-barang yang digunakan untuk illegal loging yang kepastiannya merupakan barang yang digunakan sebagai agunan utang dalam bentuk jaminan fidusia. Sebagaimana telah dijelaskan diatas bahwa barang yang dijaminkan dalam jaminan fidusia tidak dapat dilepaskan dari hak kreditur penerima fidusia akan kepentingan dari obyek jaminan tersebut. Menurut penulis, negara dalam hal ini harus mampu membedakan keberadaan barang-barang yang digunakan untuk kejahatan serta hakim hendaknya mampu melihat keberadaan barang-barang yang digunakan untuk kejahatan. Tidak dapat secara serta merta segalabarangyangdigunakanuntukkejahatan dirampas dan menjadi milik negara. Hakim harus mampu melihat secara kasuistis agar mereka yang benar-benar memiliki etikad baik mendapatkan perindungan hukum. Sebagaimana adagium dalam hukum bahwa orang yang beretikad baik mendapatkan perlindungan dari hukum.

Perampasan terhadap barang-barang jaminan fidusia yang digunakan untuk illegal logging, hanyalah sebatas digunakan untuk kepentingan pembuktian dalam proses peradilan. Bagi penulis perampasan terhadap barang jaminan fidusia tidak serta merta menjadi milik negara, karena barang tersebut walaupun digunakan untuk kejahatan, tetapi barang tersebut sifatnya tidak membahayakan yang terpenting sekali bahwa barang tersebut merupakan barang agunan tetapi disalah gunakan. Sama halnya dengan kendaraan mobil pada umumnya yang menabrak kendaraan lainnya. Mobil yang digunakan dalam peristiwa kecelakaan hanya digunakan dalam proses pembuktian dan tidak untuk menjadi milik negara.

Dengan demikian seyogyanya perampasan barang-barang jaminan fidusia tersebut setelah proses pembuktianya selesai dikembalikan kepada mereka yang paling berhak. Memang waktu pengembalian barang-barang tersebut tidak ada kaitannya dengan proses penyelesaian utang-piutang dari pihak debitur pemberi fidusia kepada pihak kreditur. Artinya kepentingan pengembalian barang-barang tersebut tidak semata-mata untuk kepentingan pihak kreditur penerima fidusia, walaupun mereka memiliki berbagai hak terhadap obyek jaminan fidusia tersebut. Apabila 
pengembalian tersebut dilakukan maka kemungkinan terjadi adalah pengembalian barang tersebut terjadi pada saat jangka waktu pelunasan utang belum jatuh tempo, atau sebaliknya dapat terjadi pengembalian barangtersebutdilakukan pada saat pelunasan utangnya sudah jatuh tempo. Persoalannya tidak terletak pada kapan pengembalian barang-barang yang dirampas, tetapi yang paling penting adalah barang-barang yang dirampas tersebut dikembalikan kepada mereka yang paling berhak. Pengembalian tersebut merupakan wujud perlindungan hukum terhadap kreditur pemegang jaminan fidusia, sehingga memberikan kepastian hukum dan kemanfaatan terhadap kreditur penerima fidusia.

Sekalipun pengembalian barangbarang yang dirampas tersebut dapat dilakukan, namun tetap saja belum cukup bagi penerima jaminan fidusia karena untuk kepentingan yang lebih besar. Itu artinya asas droit de suite tetap tidak bersifat absolut. Bagi penulis perampasan tersebut dapat diterima, namun setiap perampasan tidaklah serta merta menjadi milik negara. Seharusnya terdapat perbedaan-perbedaan terhadap barang-barang berdasarkan hasil seleksi yang tepat dan pasti terhadap barangbarang yang wajib menjadi milik negara dan mana barang-barang yang semestinya dapat dikembalikan kepada mereka yang berhak. Ketentuan tersebut seharusnya terdapat pengaturan dalam perundang-undangan atau dalam KUHP.

Berkaitan dengan pengembalian barang-barang yang dijadikan jaminan fidusia yang dirampas karena digunakan dalam kegiatan illegal logging adalah merujuk pada Pasal 46 Kitab Undang-
Undang Hukum Acara Pidana (KUHAP), ayat $1 .{ }^{31}$

Untukmengkajilebihlanjutkeberadaan asas droit de suite, dapat digunakan Pasal 46 (1) KUHAP tersebut, bahwa benda yang digunakan untuk illegal logging seharusnya dikembalikan kepada mereka yang paling berhak, yang dalam hal ini adalah pihak kreditur sebagai penerima jaminan fidusia. Mereka sesungguhnya tidak mengetahui sama sekali terhadap benda obyek jaminan fidusia digunakan sebagai alat untuk melakukan kejahatan. Demikian juga halnya dengan perampasan yang dimaksud untuk negara. Bahwa benda obyek jaminan fidusia yang digunakan sebagai alat melakukan kejahatan tidak semestinya dimusnahkan oleh negara, karena benda tersebut tidak membahayakan siapapun sebagaimana misalnya narkotika, bahan peledak dan sebagainya, yang bila disalahgunakan akan dapat menjadi malapetaka bagi siapapun juga.

Dalam hal pengembalian barangbarang yang sempat dirampas dalam tindakan illegal logging harus didasarkan pada dokumen yang sah yang keabsahannya tidak diragukan. Dengan demikian dunia perbankan atau usaha lain yang bergerak

\footnotetext{
"Benda yang dikenakan penyitaan dikembalikan kepada orang atau kepada mereka dari siapa benda itu disita, atau kepada orang atau kepada mereka yang paling berhak apabila:

Kepentingan penyidikan dan penuntutan tidak memerlukan lagi;

b. $\quad$................dst “

Pasal 46 Ayat 2 KUHAP menentukan:“apabila perkara sudah diputus, maka benda yang dikenakan penyitaan dikembalikan kepada orang atau kepada mereka yang disebut dalam putusan tersebut, kecuali jika menurut putusan hakim benda itu dirampas untuk negara, untuk dimusnahkan atau dirusakkan sampai tidak dapat dipergunakan lagi..........dst"
} 
dibidang usaha keuangan tidak ragu-ragu lagi untuk memberikan kredit dengan jaminan fidusia. Apabila dalam putusan pengadilan memutuskan bahwa barangbarang sebagai obyek jaminan fidusia yang digunakan untuk illegal logging dirampas dan menjadi milik negara, maka putusan pengadilan tersebut akan menjadi rujukan oleh pengadilan lain yang menangani kasus serupa. Menurut penulis putusan demikian akan menjadi momok pada dunia usaha, yang setiap pengajuan kredit atau pinjaman dengan jamianan fidusia akan ada kemungkinan selalu ditolak oleh calon kreditur pemberi pinjaman/kredit. Dengan demikian lama kelamaan lembaga jamianan fidusia tidak akan diminati sebagai salah satu jaminan terhadap benda bergerak. Pengaruhnya akan semakin meluas karena dunia usaha tidak berani menerima jaminan fidusia serta peminjam akan menjadi semakin melemah, karena mereka terutama pelaku usaha menengah kebawah harapannya hanya kepada barang bergerak yang mereka miliki untuk dijadikan agunan dari utang yang mereka ajukan. Apabila mereka mengajukan pinjaman dengan jaminan gadai, maka benda yang digadaikan secara yuridis wajib tidak berada ditangan debitur pemilik obyek gadai. Hal tersebut berakibat kembalinya pola lama pada waktu lembaga jaminan fidusia tidak ada. Dalam sejarahnya justru adanya lembaga jaminan fidusia adalah tidak mampunya lembaga gadai memberikan satu-satunya solusi dunia usaha yang ingin melakukan pinjaman utang. Penerobosan lembaga gadai tersebut terjadi secara yuridis sejak Mahkamah Agung Belanda menjatuhkan putusan tgl 25 Januari 1929 dalam kasus Bierbrouwerij Arrest. Dalam jaminan fidusia obyek jaminan masih berada ditangan pemberi jaminan fidusia, tidak seperti pada jaminan gadai apabila obyek jaminan masih ditangan pemberi gadai, maka gadainya menjadi tidak sah.

\section{Gugatan Berdasarkan Pasal $\mathbf{1 3 6 5}$ BW Indonesia.}

Gugatan dari pihak penerima jaminan merupakan tindakan yang bersifat represif untuk mendapatkan perlindungan secara yuridis. Gugatan tersebut dilakukan adalah tindakan yang paling terakhir setelah upaya perlindungan yang lainnya tidak memberikan harapan yang berarti. Gugatannya tidaklah didasarkan atas wanprestasi, tetapi gugatan ganti kerugian yang didasarka atas perbuatan melanggar hukum berdasarkan ketentuan Pasal 1365 BW Indonesia.

Terdapat kemungkinan bahwa obyek jaminan fidusia yang digunakan untuk melakukan kejahatan adalah telah disewakan oleh pemberi fidusia. Apabila demikian halnya, maka menurut Pasal 23 Ayat (2) UUJF pemberi jaminan fidusia dilarang menyewakan obyek jaminan fidusia. Berdasarkan Pasal 36 UUJF pihak pemberi jamianan fidusia yang telah menyewakan obyek jaminan tersebut diancam dengan pidana penjara paling lama 2 (dua) tahun dan denda paling banyak Rp. 50.000.000 (lima puluh juta rupiah).

Sesungguhnya bagi pihak penerima fidusia dalam hal ini masih tetap mengalami kerugian akibat perbuatan menyewakan yang dilakukan oleh si pemberi fidusia. Yang paling dikehendaki oleh penerima fidusia adalah pengembalian harta senilai aset yang telah diberikan kepada pemberi fidusia. Ancaman hukuman kepada pemberi fidusia tidak menyelesaikan hubungan kontraktual yang pernah dilakukan antara 
pihak penerima dan pemberi fidusia. Pihak penerima fidusia tetap mengalami kerugian secara ekonomis sekalipun pihak pemberi fidusia telah dijatuhi hukuman pidana.

Penjatuhan sanksi terhadap pihak debitur pemberi jaminan fidusia tidak menyelesaikan hubungan kontraktual yang dilakukan antara pemberi dan penerima fidusia. Pada umumnya penyelesaian hubungan kontraktual yang berkaitan dengan wanprestasi adalah tuntutan ganti kerugian berdasarkan wanprestasi. Sementara penyewaan benda jaminan fidusia yang dilakukan oleh pemberi fidusia merupakan suatu pelanggaran terhadap ketentuan UUJF. Dengan demikian adalah layak diancam dengan sanksi pidana.

Jadi asas droit de suite belumlah bersifat mutlak. Dalam hal ini yang dibutuhkan pengaturan dalam UUJF untuk mengisi kekosongan sebagai jaminan atas pemberlakuan asas droit de suite yaitu bahwa pihak pemberi jaminan fidusia yang telah melakukan perbuatan melanggar hukum diwajibkan untuk memberikan penggantian kerugian senilai jaminan yang telah diberikan. Jadi dalam hal ini apabila perbuatan melanggar hukumnya telah terbukti maka pihak pemberi jaminan fidusia secara langsung dan dipaksakan memberikan ganti kerugian, yang bila perlu dilakukan penyitaan atas harta benda baik bergerak ataupun benda tetap yang ia miliki. Dengan demikian gugatan ganti kerugian berdasarkan Pasal 1365 BW Indonesia tetap perlu dilakukan.

\section{SIMPULAN DAN SARAN}

\subsection{Simpulan}

Bahwa ketentuan Pasal 20 UUJF tersebut yang memuat asas droit de suite masih mengandung kelemahan yakni UUJF tidak menentukan pengganti obyek jaminan fidusia ketika obyek jaminan dirampas untuk kepentingan negara ataupun tidak ada kewajiban dari hakim pada waktu proses dan putusan persidangan dilakukan untuk mengembalikan obyek jaminan fidusia.

Perampasan obyekjaminan fidusia oleh negara yang digunakan untuk kegiatan illegal loging adalah untuk melindungi kepentingan yang lebih besar dari pada kepentingan individual yang dimiliki oleh penerima jaminan fidusia. Namun demikian dikaji dari KUHP dan KUHAP, apabila perkaranya sudah diputus oleh Pengadilan, maka obyek jaminan tersebut wajib dikembalikan kepada mereka yang paling berhak.

Langkah represif yang dapat dilakukan oleh penerima fidusia dalam hal obyek jaminan fidusia dirampas oleh negara adalah melakukan gugatan ganti kerugian berdasarkan Pasal 1365 BW Indonesia. Gugatan tersebut dilakukan karena pihak pemberi fidusia melakukan perbuatan melanggar hukum yang mengakibatkan kerugian pada pihak penerima fidusia sebagai kreditur, karena tidak dapat memberikan kepastian jaminan tehadap pelunasan pinjaman yang telah dilakukan oleh pihak pemberi fidusia.

\subsection{Saran}

2.1. Untuk mengantisipasi etikad buruk dari pihak pemberi fidusia sebagai debitur masih diperlukan lagi pengaturan dalam UUJF yang berupa perjanjian tambahan khususnya nilai kredit dan jaminan yang relatif besar untuk memberikan kepastian hukum terhadap kreditur sebagai menerima fidusia. Pengaturan yang dibutuhkan adalah menegaskan bahwa hakim memiliki 
wewenang untuk mengembalikan obyek jaminan fidusia yang dirampas untuk negara. Obyek jaminan fidusia tidak harus menjadi milik negara sebagaimana ditentukan dalam Pasal 42 KUHP. Sehingga pihak kreditur mendapatkan perlindungan hukum.

2.2. Dalam hal pihak penerima fidusia melakukan gugatan ganti kerugian berkaitan dengan kejahatan yang dilakukan dengan menggunakan obyek jaminan fidusia, maka pengadilan secepatnya melakukan penyitaan terhadap barang lain dari pihak pemberi fidusia untuk meyakinkan serta memastikan akan pelunasan utang yang masih tersisa dari pihak pemberi fidusia.

\section{DAFTAR PUSTAKA.}

Bernard Arief Sidharta, Refleksi Tentang Struktur Ilmu Hukum. Mandar Maju. Bandung,.2000.

Bryan A Garner,. Black's Law Dictionary,

Eighth Edition, West, a Thomson Business St. Paul, MN, 2004.

Djoni S Gazali dan Rachmadi Usman,

Hukum Perbankan, Sinar Grafika, Jakarta 2010

Frieda Husni Hasbullah, Hukum Kebendaan

Perdata: Hak-Hak Yang Memberi Kenikmatan, Jilid I, Ind-Hill-Co, Jakarta, 2002.

Freida Husni Hasbullah, Hukum Kebendaan

Perdata: Hak-hak Yang Memberi Jaminan, Jilid II, Ind-Hill-Co, Jakarta, 2005.

Hadjon, M Philipius dan Tatiek Sri Djatmiati, Argumentasi Hukum. Gajah Mada University Press, Yogyakarta, 2000.

Hadjon, M Philipus, Perlindungan Hukum

Bagi Rakyat Indonesia, Perdaban, Surabaya, Edisi Khusus, 2007
Koesparmono Irsan, Hukum dan Hak Asasi Manusia, Yayasan Brata Bhakti, Jakarta, 2009.

Martin Basiang, The Contemporary Law Dictionary, Red \& White Publishing, Indonesia, 2009.

Marzuki,Peter Mahmud, Penelitian Hukum, Kencana Prenada Media Group, Jakarta, 2006

Pengantar Ilmu Hukum, Kencana

Prenada Media Group, Jakarta 2009.

Ranuhandoko, Terminologi Hukum, Sinar Grafika, Jakarta 2006.

Simamora, Yohanes Sogar, Hukum Perjanjian Prinsip Hukum Kontrak Pengadaan Barang dan Jasa oleh Pemerintah, LaksBang PRESSindo, 2009

Sudikno Mertokusumo, Penemuan Hukum Sebuah Pengantar. Cet. Kelima Liberty Yogyakarta.2007 .

\section{Pengantar, Universitas Atma Jaya,} Yogyakarta, 2010.

Sunaryati Hartono C.F.G, Penelitian Hukum Di Indonesia Pada Akhir Abad ke 20, Alumni Bandung.1994

Tan Kamelo, Hukum Jaminan Fidusia, Alumni Bandung, 2004.

Webster's New World Law Dictionary, Wiley Publishing, Inc. 2006,

Yatimin Abdullah, Pengantar Studi Etika, Raja Grafindo, Jakarta, 2006

Zein, Sulta Muhammad, Kamus Umum Bahasa Indonesia, Sinar Harapan, Jakarta 1996

\section{LAIN-LAIN:}

Jurnal Konstitusi, Vol.3. No. 2 Mei 2006. 